\title{
EFFECTS OF TYRE STEEL FIBRE REINFORCEMENT ON SANDCRETE BLOCKS
}

\author{
N. M. Musa ${ }^{1, *}$ and M. Abubakar ${ }^{2}$ \\ 1, 2, DePartment of Civil Engineering, Kano Univ. of SCIENCE AND TEChNology, Wudil Kano State, NiGERIA \\ E-mail addresses: ${ }^{1}$ mnuruddeen@gmail.com, ${ }^{2}$ inuwaimam90@gmail.com
}

\begin{abstract}
This study investigates the effect of tyre steel fibres on compressive strength of hollow sandcrete blocks. A total of 36 number $450 \mathrm{~mm} \times 225 \mathrm{~mm} \times 225 \mathrm{~mm}$ hollow sandcrete blocks with $0 \%, 1 \%, 2 \%$, and $3 \%$ of tyre steel fibre content were produced and tested for density, compressive strength and water absorption. From the test results, the densities of blocks increase with an increases in fibres contents. As at 28 days, the density increases from $1395.20 \mathrm{~kg} / \mathrm{m}^{3}$ for $0 \%$ to $1425.57 \mathrm{~kg} / \mathrm{m}^{3}$ for $3 \%$ fibre content. Also, the water absorption decreases with increases in tyre steel fibres. Furthermore, the compressive strength increases with increase in tyre steel fibres contents. At 28 days, there was an increase in compressive strength of $6 \%, 58 \%$ and $95 \%$ for $1 \%, 2 \%$ and $3 \%$ fibre contents respectively. It is concluded that addition of tyre steel fibres significantly improves the performance of hollow sandcrete blocks.
\end{abstract}

Keywords: Sandcrete blocks; Tyre Steel Fibre; compressive strength, water absorption

\section{INTRODUCTION}

Hollow Sandcrete block is a very popular building material in Nigeria, its importance as part of local building materials cannot be over emphasized in building and construction industry of the country $[1$, 2]. Traditionally, hollow sandcrete blocks contain a mixture of sand, cement and water $[3,4]$. The incessant occurrences of building collapse in Nigeria and its attendant loss of lives and properties have become worrisome and of great concern. These failures have been attributed to various reasons, among which are poor quality and sub-standard building material, notable among them sandcrete blocks [5-8]. This among others, necessitated the construction industry to focused from the use of conventional construction materials to newer materials that can increase the quality of sandcrete blocks $[9,10]$.

In recent years, the construction industry has shown significant interest in the use of fibre-reinforced concrete owing to the improvements in structural performance it can provide, compared to traditional plain concrete [11]. The main role of fibre reinforcement in concrete is to control cracking and to alter the behavior of the material once the matrix has cracked, by bridging across these cracks and so providing some post-cracking ductility $[12,13]$. Most of the times the use of hollow sandcrete blocks lead to micro cracks on the walls of the structure after or during construction due to their low tensile strength. Fibre reinforced Sandcrete blocks, just like fibre reinforced concrete may be able to overcome these micro-cracks associated with hollow sandcrete blocks based materials. Incorporation of short discrete steel fibres in a relatively hollow sandcrete blocks matrix, might gives the hollow sandcrete blocks materials a maximum ductility to overcome its low tensile strength properties. Similarly [14] reported that addition of polythene fibres to sandcrete blocks improves the tensile strength and limit the propagation of cracks, although it has little effect on the compressive strength. Recycled tyre steel fibres are obtained from recycling of scrap tyres [15]. They are obtained either by shredding or by pyrolysis (burning) process. Large quantities of post-consumer tyres are generated each year globally, The use of recycled tyre will alleviate the growing problem of waste tyre disposal [16]. According to [17] the thickness of fibres obtained from shredding was around $0.23 \mathrm{~mm}$ whereas the thickness of those obtained by pyrolysis ranged from 0.8 to $1.5 \mathrm{~mm}$.

The aim of this research is to determine the effects of using steel fibre from used or recycled tyres on the performance of sandcrete blocks. 


\section{MATERIALS AND METHODS}

\subsection{Materials}

\subsubsection{Cement}

The cement used in conducting this research was Portland-limestone cement produced by Dangote cement company plc of grade 42.5 . This complied with CEM II of NIS-444 Part 1 [18].

\subsubsection{Fine Aggregate}

River sand was used as fine aggregate, it was clean, sharp and free from clay, loam, dirt and any other deleterious materials. The fine aggregate was dried so that water cement ratio would not be affected. Sieve analysis was carried out on the aggregate. The specific gravity of the aggregate was determined to be 2.05 .

\subsubsection{Water}

The water used for the research was free from salt and other deleterious materials.

\subsubsection{Tyre Steel Fibre}

Tyre steel fibres were obtained from burning scrap tyres of light trucks. The steel fibres used were washed and free from carbon black. The fibres used in this research were characterized by different lengths and diameters. Samples of 50 tyre steel fibres were extracted randomly and analyzed. The diameter of each fibre was recorded by a Vanier Calliper tool and the length was recorded by using a ruler. Averagely, the fibres are $30 \mathrm{~mm}$ in length and $1.2 \mathrm{~mm}$ in diameter. Steel fibres that are of similar materials to recycled tyre steel are reported to have specific gravity of $5.85-7.85$ [19-21]

\subsection{Methods}

\subsubsection{Hollow Sandcrete Block Production}

Sandcrete hollow blocks of sizes 225 x 225 x 450mm were produced using the materials described in 2.1. The mix ratio used was 1:8 (one part of binder to eight part of sand) at $0 \%, 1 \%, 2 \%$ and $3 \%$ of tyre steel fibres contents. The mixes were done manually. Nine (9) numbers of blocks were produced for each additives, a total number of 36 blocks were cast. The quantities of materials (cement, sand and tyre steel fibre) obtained from the mix design were measured in each case with the aid of weighing balance. The summary of the mix design is shown in Table 1 . The cement, sand and tyre steel fibres were mixed thoroughly together to obtain a homogeneous mixture. Water was then added on to the mixture in the required quantity. The mixture was further turned with shovels until a mix of the required workability was obtained. The resulting mortar was transferred to the steel hollow mould and compacted. The content was de-molded as a fresh hollow block. The block samples were cured by sprinkling water twice in the morning and evening daily before testing at 3,7 and 28 days.

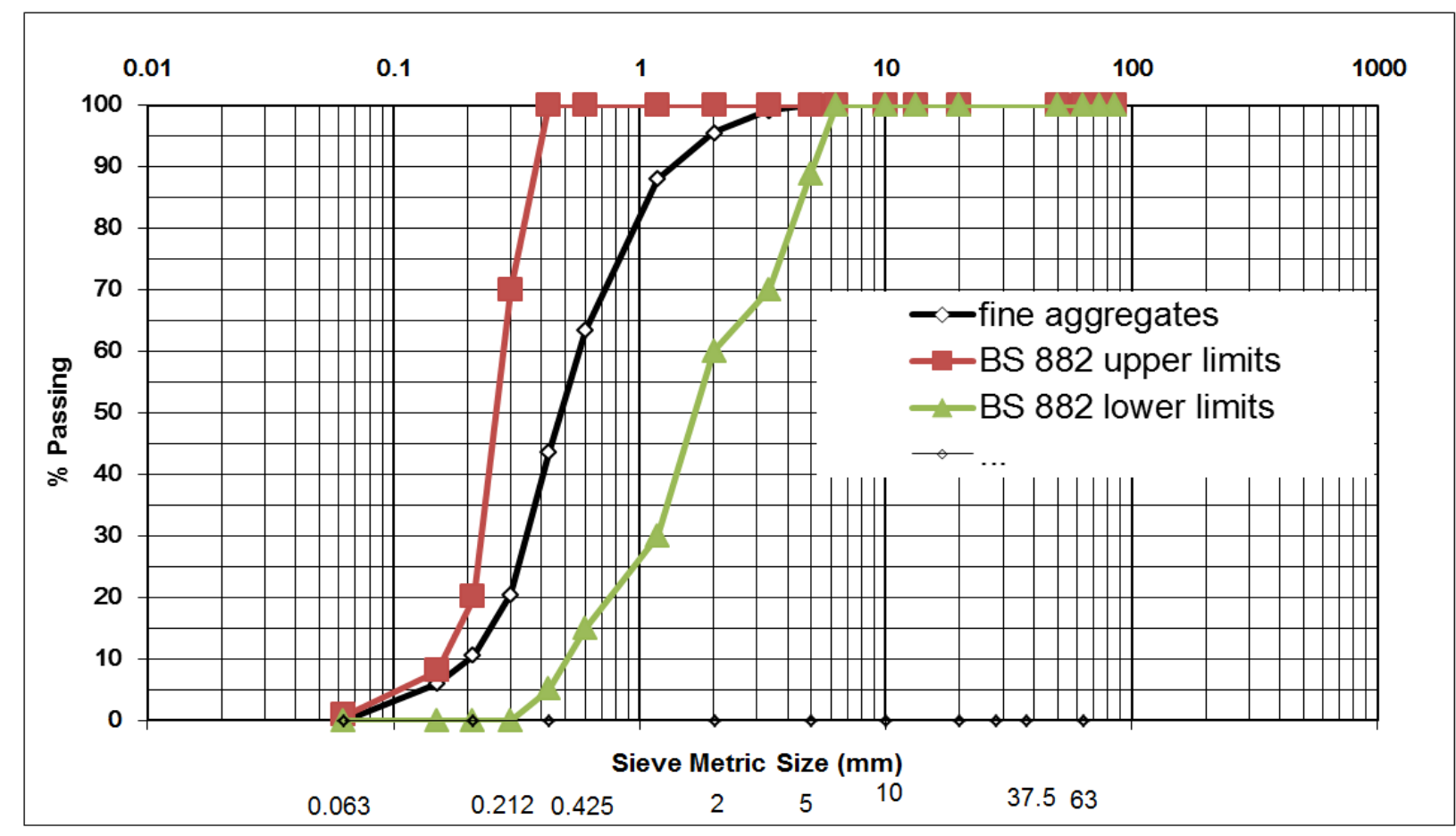

Figure 1: Particle size distribution of fine aggregate 
Table 1 Quantities of constituent materials $(\mathrm{kg})$

\begin{tabular}{llllll}
\hline Fibre contents & Cement & Fine Aggregates & Water & W/C Ratio & Steel fibre \\
\hline $0 \%$ & 22.95 & 183.60 & 11.48 & 0.50 & 0.00 \\
$1 \%$ & 22.95 & 183.60 & 11.48 & 0.50 & 2.07 \\
$2 \%$ & 22.95 & 183.60 & 11.48 & 0.50 & 4.13 \\
$3 \%$ & 22.95 & 183.60 & 11.48 & 0.50 & 6.20 \\
\hline
\end{tabular}

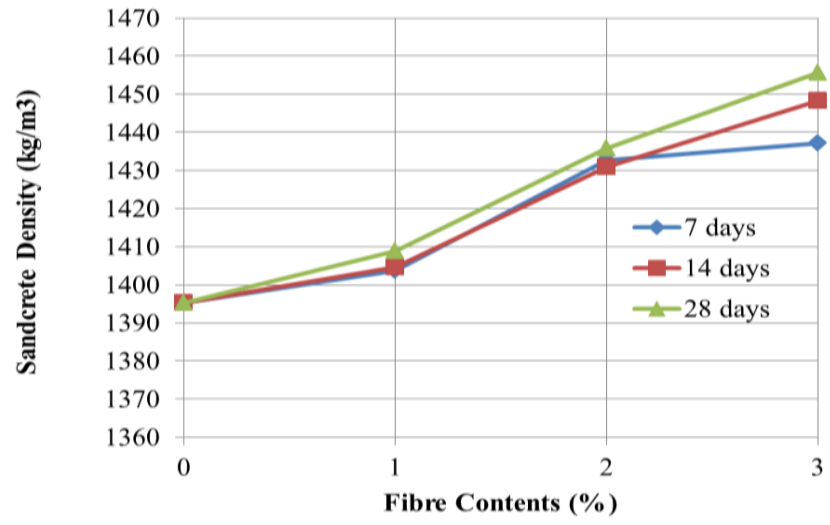

Figure. 2: Effect of Fibre contents on Density.

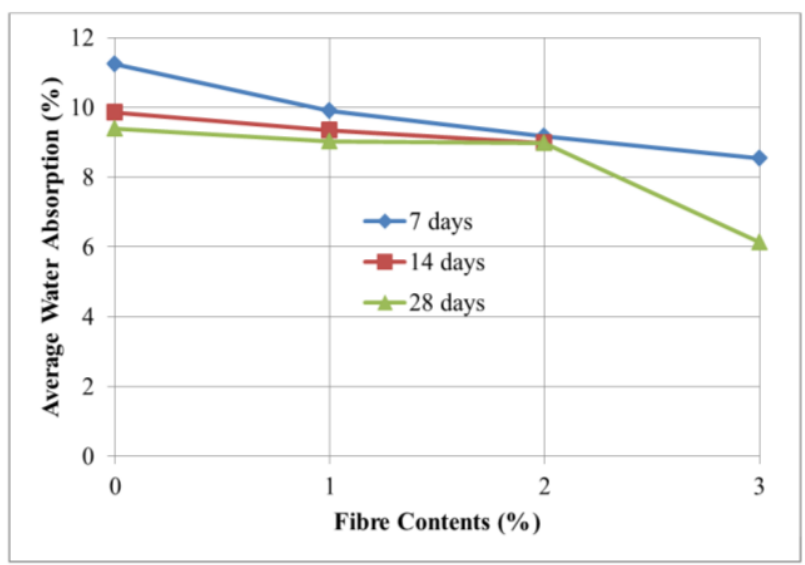

Figure. 3 Effect of Fibre contents on sandcrete water absorption

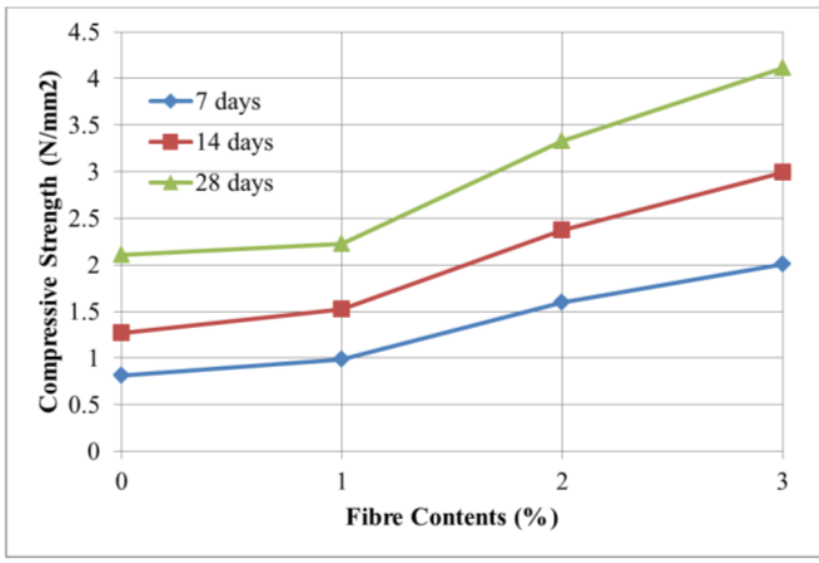

Figure. 4 Effect of Fibre contents on sandcrete compressive strength

\subsubsection{Compressive Strength Test}

The compressive strength of the block samples was determined in accordance with NIS-87 [22]. The weights of the block samples were always taken before the compressive strength test was conducted. Three sample blocks were crushed each at 3, 7 and 28 days after casting at different fibre additive levels using compressive testing machine.

\subsubsection{Water Absorption Test}

The water absorption test was conducted on the block samples in accordance with NIS-87 [22] at 3, 7 and 28 days.

\section{RESULT DISCUSSION}

\subsection{Particle size distribution of fine aggregate}

The result of particle size distribution of fine aggregate is presented in Figure 1. From the figure, the fine aggregate falls into zone 2 of the BS 882 [23]. Hence the fine aggregate is suitable for making sandcrete blocks.

\subsection{Hollow sandcrete blocks density.}

Figure 2 shows the result of density test for sandcrete blocks having $0 \%, 1 \%, 2 \%$ and $3 \%$ tyre steel fibre contents. From Figure 2, the density of the blocks increases with an increase in the fibres contents (i.e. the higher the fibres contents the higher the density and vice-versa) in all the curing ages. This increase in density is due to higher density of tyre steel fibres than those of the other constituents used in sandcrete block production.

\subsection{Water Absorption}

Water absorption is the measure of the amount of water that block absorbed in a specified period of 24 hours in cold water. The result of the test is presented in Figure 3. The amounts of water absorbed by the blocks are within the limit specified by the code [22] (absorbed water shall not exceed $12 \%$ of the dry mass). It was also realized that the rate of water absorption decreases with an increase in fibres contents. The decreases in water absorption can be attributed to the inability of steel fibre in the sandcrete to absorb water, as the rate of water absorption of steel 
is approximately negligible compared to the other constituents.

\subsection{Compressive Strength}

The summary of compressive strength test result on sandcrete blocks with $0 \%, 1 \%, 2 \%$ and $3 \%$ of fibre content after 7, 14 and 28 days of curing is presented in Figure 4. According to NIS 87 [22], the average minimum compressive strength of load bearing hollow blocks for hand compaction is $2.0 \mathrm{~N} / \mathrm{mm}^{2}$. In view of this, all the specimens containing fibre performed better than the control specimens $(0 \%)$ as they have conformed to the standard.

The compressive strength of sandcrete blocks increase with increase in tyre steel fibre contents. At 28 days, there was an increase in compressive strength of $6 \%$,

$58 \%$ and $95 \%$ for $1 \%, 2 \%$ and $3 \%$ fibre contents respectively. The tyre steel fibre improves the strength of the blocks by providing a better bonding within the mortar matrix. It was observed during the experimental works that there are fewer cracks in the blocks with the steel fibre during failure and the crack width was comparatively smaller compared to the control. It was also observed that rusting occurs on the sandcrete blocks having fibres, with $3 \%$ fibre content having the highest rusts. In view of this fibre contents exceeding $3 \%$ is not recommended as the rust will weaken the bonding. Also, extra care should be employed in handling blocks strengthen with the steel fibres as the fibre protrusion can be harmful.

\section{CONCLUSIONS}

The following conclusions were drawn from this study:

1. From the study it can be concluded that; addition of tyre steel fibres improves the performance of the sandcrete blocks at all ages.

2. The density of the blocks increases with an increase in the fibre contents (the higher the fibre contents the higher the density and vice-versa).

3. The rate of water absorption declines with an increase in fibre contents, the amount of water absorbed by the blocks are within the limit specified by the code. (absorbed water shall not exceed $12 \%$ of the dry mass).

4. The addition of tyre steel fibre causes rusting in sandcrete blocks. There is a need for more research on the durability of sandcrete blocks having tyre steel fibres.

\section{REFERENCES}

[1] Abdullahi, M., Compressive strength of sandcrete blocks in Bosso and Shiroro areas of Minna, Nigeria. $A U J T, 2005.9(2)$ : p. 126-131.

[2] Anosike, M. and A. Oyebade, Sandcrete blocks and quality management in Nigeria Building Industry. Journal of Engineering, Project, and Production Management, 2012. 2(1): p. 37

[3] Oyekan, G. and O. Kamiyo, Effect of Nigerian rice husk ash on some engineering properties of sandcrete blocks and concrete. Research Journal of Applied Sciences, 2008. 3(5): p. 345-351.

[4] Ewa, D. and J. Ukpata, Investigation of the compressive strengths of commercial sandcrete blocks in Calabar Nigeria. International Journal of Engineering and Technology, 2013. 3(4): p. 477-482.

[5] Hijab, M., A. Halilu, and A. Hadi, Compressive strength of marketed sandcrete blocks produced in Yola, Nigeria. Journal of Engineering and Applied Sciences, 2010. 2: p. 74-81.

[6] Omopariola, S.S., A Comparative Study of the Hygroscopic Properties of Hollow and Solid Sandcrete Blocks. Journal of Emerging Trends in Engineering and Applied Sciences, 2015. 6(7): p. 144-150.

[7] Oladeji, O. and 0. Awos, Assessment of Materials and Process Variables on Regulatory Compliance of Sandcrete Blocks: A Case Study of Ogbomoso, Nigeria. Int. Journal of Engineering Research and Applications Vol. 3, Issue 6, Nov-Dec 2013, pp.793-799

[8] Odeyemi, S.O., M.A. Akinpelu, O.D. Atoyebi, and K.J. Orire, Quality assessment of sandcrete blocks produced in Adeta, Kwara State, Nigeria. Nigerian Journal of Technology, 2018. 37(1): p. 53-59.

[9] Tyagher, S., J. Utsev, and T. Adagba, Suitability of saw dust ash-lime mixture for production of Sandcrete hollow blocks. Nigerian Journal of Technology, 2011. 30(1): p. 79-84.

[10] Okafor, F. and E. Egbe, Models for predicting compressive strength and water absorption of laterite-quarry dust cement block using mixture experiment. Nigerian Journal of Technology, 2017. 36(2): p. 366-372.

[11] Lie, T. and V. Kodur, Thermal and mechanical properties of steel-fibre-reinforced concrete at elevated temperatures. Canadian Journal of Civil Engineering, 1996. 23(2): p. 511-517.

[12] Bentur, A. and S. Mindess, Fibre reinforced cementitious composites. 2006: CRC Press. 
[13] Vajje, S., Study on addition of the natural fibers into concrete. International Journal of Scientific \& Technology Research, 2013. 2(11): p. 213-218.

[14] Ijalana, F., J. Afoloayan, and O. Adeleke, Effects of polythene fibres on selected properties of sandcrete blocks. Nigerian Journal of Technology, 2016. 35(1): p. 37-42.

[15] KÖROĞLU, M.A., Mechanical characterization of recycled tires in concrete. Selçuk Üniversitesi Mühendislik, Bilim ve Teknoloji Dergisi, 2016. 4(4): p. 330-336.

[16] Rostami, H., J. Lepore, T. Silverstraim, and I. Zundi. Use of recycled rubber tires in concrete. in Proceedings of the international conference on concrete. 2000. London, United Kingdom: Thomas Telford Services Ltd.

[17] Pilakoutas, K., K. Neocleous, and H. Tlemat, Reuse of tyre steel fibres as concrete reinforcement. Proceedings of the ICE-Engineering Sustainability, 2004. 157(3): p. 131-138.

[18] NIS-444., Quality standard for ordinary Portland cement. Standard Organization of Nigeria, Lagos, Nigeria, 2003.
[19] Löfgren, I., Fibre-reinforced Concrete for Industrial Construction-a fracture mechanics approach to material testing and structural analysis. 2005: Chalmers University of Technology.

[20] Mohammed, H.J., A.H. Abbas, and M.A. Husain, Using Of Recycled Rubber Tires And Steel Lathes Waste As Fibbers To Reinforcing Concrete. Iraqi Journal of Civil Engineering, 2013. 9(1): p. 27-38.

[21] Beaudoin, J.J., Handbook of Fiber-Reinforced Concrete. Principles, Properties, Developments and Applications. USA: William Andrew Publishing, 1990.

[22] NIS-87, N.I.S., Standard for Sandcrete Blocks in Nigeria. Standards Organisation of Nigeria, Lagos, 2004.

[23] BS882, Aggregates from natural Sources for concrete. British Standards Institute, 389 Chiswick High Road, London, W4 4AL, http://www.bsi-global.com/. , 1983. 